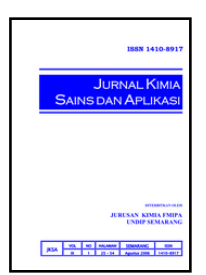

\title{
Pembuatan dan Penentuan Nilai Efisiensi Sel Surya Berpewarna Tersensitisasi dengan Senyawa Antosianin dari Buah Manggis (Garcinia mangostana L.) sebagai Pewarna Pensensitisasi
}

\author{
Joko Suryadi $^{\mathrm{a}}$, Gunawan ${ }^{\mathrm{a}}$, Abdul Haris ${ }^{\mathrm{a}}$ \\ a Analytical Chemistry Laboratory, Chemistry Department, Faculty of Sciences and Mathematics, Diponegoro University, Jalan Prof. \\ Soedarto, Tembalang, Semarang 50275 \\ * Corresponding author: gunawan@live.undip.ac.id
}

\begin{tabular}{|c|c|}
\hline Article Info & Abstract \\
\hline $\begin{array}{l}\text { Keywords: } \\
\text { DSSC, anthocyanin, } \\
\text { mangosteen, dye } \\
\text { sensitizer }\end{array}$ & $\begin{array}{l}\text { The preparation and determination of DSSC's efficiency value with anthocyanin } \\
\text { compound from mangosteen's rind as dye sensitizer has been investigated. The } \\
\text { objectives of this work were preparing the DSSC device, characterizing its components } \\
\text { and determining the efficiency value. Working electrode is made of } \mathrm{TiO}_{2} \text { thin film that } \\
\text { adsorbed anthocyanin from mangosteen's rind, counter electrode is made of carbon and } \\
\mathrm{I}^{-} / \mathrm{I}_{3}^{-} \text {electrolyte as redox couple. DSSC's characterizations are } \mathrm{TiO}_{2} \text { crystallinity, pore } \\
\text { size and thickness of } \mathrm{TiO}_{2} \text { thin film, maximum wavelength absorption of dye, analysis } \\
\text { of functional group and bond interaction between TiO } \mathrm{T}_{2} \text { and anthocyanin. The efficiency } \\
\text { value of DSSC is determined by current-voltage curve method. The result shown that } \\
\text { components of DSSC was able to build the DSSC device by its characterization and the } \\
\text { efficiency value of DSSC device was } 2,2 \times 10^{-3} \% \text {. }\end{array}$ \\
\hline
\end{tabular}

\begin{abstract}
Abstrak
Telah dilakukan penelitian mengenai pembuatan dan penentuan nilai efisiensi DSSC dengan senyawa antosianin dari kulit buah manggis sebagai pewarna pensensitisasi. Penelitian ini bertujuan untuk membuat rancangan DSSC, mengkarakterisasi penyusunnya dan menentukan nilai efisiensinya. Penelitian dilakukan dengan pembuatan elektroda kerja (working electrode) dari lapis tipis $\mathrm{TiO}_{2}$ yang mengadsorb antosianin kulit buah manggis, elektroda perlawanan (counter electrode) dari karbon dan elektrolit $\mathrm{I}^{-} / \mathrm{I}_{3}{ }^{-}$sebagai pasangan redoks. Karakterisasi DSSC meliputi kristalinitas $\mathrm{TiO}_{2}$, ukuran rongga dan ketebalan lapis tipis $\mathrm{TiO}_{2}$, serapan panjang gelombang maksimum zat pewarna, analisis gugus fungsi antosianin serta ikatan antara $\mathrm{TiO}_{2}$ dengan molekul antosianin. Nilai efisensi DSSC ditentukan dengan metode kurva arus dan tegangan. Hasil penelitian menunjukkan karakterisasi masing-masing penyusun DSSC telah memenuhi syarat sebagai rancangan DSSC dan nilai efisiensi rancangan DSSC adalah sebesar 2,2 $\times 10^{-3} \%$.
\end{abstract}

Kata kunci: DSSC, antosianin, buah mangggis, pewarna pensensitasi

\section{Pendahuluan}

Energi merupakan kebutuhan yang tidak dapat dipisahkan dari kehidupan makhluk hidup di bumi. Selama ini kebutuhan energi masih sangat bergantung pada bahan bakar fosil yang merupakan sumber energi yang tak terbarukan dan lama kelamaan akan habis.
Sementara emisi berupa senyawa-senyawa karbon seperti karbon dioksida dan karbon monoksida yang dihasilkan dari pembakaran bahan bakar fosil seluruh dunia pada tahun 1998 adalah $7 \times 10^{12} \mathrm{~kg}$ yang merupakan jumlah yang sangat besar [1].

Dengan semakin menipisnya sumber energi fosil tersebut, di dunia sekarang ini terjadi pergeseran dari 
penggunaan energi yang tidak terbarukan menjadi sumber energi yang terbaharukan. Sumber energi terbaharukan dapat berasal dari pemanfaatan energi matahari, angin, air dan bahan bakar dari tumbuhan hidup. Penggunaan solar cell (sel surya) dalam pemanfaatan energi terbaharukan merupakan alternatif yang sangat potensial. Hal itu dikarenakan jumlah energi matahari yang sampai ke bumi sangat besar, pasokan energi surya yang diterima permukaan bumi mencapai $3 \times 10^{24}$ joule pertahun. Jumlah energi sebesar itu setara dengan 10.000 kali konsumsi energi di seluruh dunia saat ini. Dengan kata lain dengan menutup 0,1 \% saja permukaan bumi dengan piranti sel surya yang memiliki efisiensi $10 \%$ sudah mampu menutupi kebutuhan energi di seluruh dunia saat ini [1].

Sel surya yang banyak digunakan sekarang ini adalah sel surya berbasis silikon. Walaupun sel surya sekarang didominasi oleh bahan silikon, masalah mahalnya biaya produksi menjadi suatu kendala. Selain itu kekurangan dari sel surya berbasis silikon adalah penggunaan bahan kimia berbahaya pada proses fabrikasinya [2].

Seiring dengan perkembangan teknologi nano, secara bertahap sel surya berbasis silikon mulai digantikan sel surya generasi terbaru yaitu sel surya dengan zat warna peka cahaya atau Dye-sensitized Solar Cell (DSSC). Keunggulan dari DSSC adalah tidak memerlukan bahan dengan kemurnian tinggi sehingga biaya produksinya relatif rendah. Berbeda dengan sel surya konvensial yang semua proses melibatkan bahan silikon itu sendiri, pada DSSC absorpsi cahaya dan pemisahan muatan listrik terjadi pada proses yang terpisah. Cahaya diserap oleh molekul pewarna dan pemisahan muatan oleh semikonduktor anorganik kristal nano yamg memiliki celah pita besar. Salah satu semikonduktor yang sering digunakan adalah titanium dioksida $\left(\mathrm{TiO}_{2}\right)$. Hal itu dikarenakan $\mathrm{TiO}_{2}$ relatif murah, banyak dijumpai, inert, tidak beracun dan merupakan bahan yang biokompatibel [3]

Komponen penting lain dalam DSSC adalah dyesensitizer. Dye-sensitizer yang digunakan dalam DSSC pada umumnya adalah senyawa kompleks ruthenium. Penelitian mengenai penggunaan kompleks rhutenium sebagai pewarna pada komponen DSSC telah dilakukan dan mencapai efisiensi yang paling tinggi. Akan tetapi, kompleks ini masih sangat mahal dan mengandung logam berat dalam senyawanya sehingga merugikan apabila ditinjau dari sudut pandang lingkungan. Oleh karena itu, digunakan senyawa pewarna alternatif yang mempunyai fungsi yang sama dengan kompleks ruthenium [4].

Senyawa alternatif pengganti kompleks rhutenium yang dapat digunakan dalam pembuatan DSSC adalah antosianin karena mampu menyerap spektrum sinar matahari yang paling besar yaitu pada rentang warna biru, biru kehijauan dan hijau muda. Selain itu antosianin sangat sensitif terhadap cahaya dan mampu diuraikan oleh mikroba sehingga tidak membahayakan lingkungan [2]. Antosianin mudah ditemukan di alam sebagai pigmen dalam tumbuh-tumbuhan yang berwarna merah, ungu maupun biru pada buah ataupun bunga [5].

Berbagai penelitian mengenai penggunaan senyawa antosianin sebagai dye-sensitizer dari berbagai jenis tumbuhan telah dilakukan antara lain menggunakan senyawa antosianin dari bunga Rosella (Hibiscus sabdariffa L.) yang menghasilkan nilai efisiensi maksimal sebesar 0,7\% [4]. Penggunaan senyawa antosianin dari California Blackberries (Rubus ursinus) sebagai dye-sensitizer juga telah dilakukan dan menghasilkan efisiensi sebesar $0,56 \%$ di bawah sinar matahari langsung [6].

Buah manggis merupakan salah satu buah yang mengandung pigmen antosianin pada kulitnya dan belum banyak penelitian yang mengupas penggunaannya sebagai dye-sensitizer. Oleh karena itu, pada penelitian ini digunakan senyawa antosianin dari buah manggis sebagai pewarna alternatif dari kompleks ruthenium. Senyawa antosianin dari buah manggis berupa cyanidin-3-spohoroside dan cyanidin-3-glucoside [7]. Buah manggis mudah dijumpai karena secara luas tersebar di seluruh kawasan hutan tropis Asia Tenggara termasuk Indonesia.

\section{Metode}

\section{Bahan dan Alat}

Bahan-bahan yang digunakan dalam penelitian ini adalah kulit buah manggis, Polivinil alkohol, kaca substrat $\mathrm{LCD}, \mathrm{TiO}_{2}$ (Merck), etanol teknis, metanol proanalysis, asam asetat proanalysis, Kalium Iodida proanalysis, Iod proanalysis, asetonitril proanalysis, serbuk karbon, kertas saring dan aluminium foil.

Peralatan yang digunakan adalah peralatan gelas, furnace, neraca digital (KERN), alu, mortar, cawan keramik, hotplate, klip, kabel, penjepit buaya, isolasi, multimeter digital (HELES), Spektrofotometer ultraviolet-tampak (T60 U), scanning electron microscope (JSM-35C), difraktometer sinar X (Pan Analytical), spektrofotometer inframerah (Themo Nicolet AVATAR 360) dan resistor variabel 10k $\Omega$ (ALPHA).

\section{Pembuatan Pasta $\mathrm{TiO}_{2}$}

Polivinil Alkohol (PVA) sebanyak 0,5 g ditambahkan ke dalam akuades, kemudian diaduk sambil dipanaskan di atas tungku pemanas sampai membentuk suspensi sebagai pengikat $\mathrm{TiO}_{2}$. Suspensi ditambahkan pada bubuk $\mathrm{TiO}_{2}$ sebanyak 4,5 g. Campuran digerus dengan mortar sampai terbentuk pasta yang baik untuk dilapiskan [8].

\section{Ekstraksi Pigmen Kulit Buah Manggis}

Kulit buah manggis dihaluskan dengan alu dan mortar kemudian ditambahkan metanol:asam asetat:air (25:4:21 perbandingan volume) sebanyak $10 \mathrm{~mL}$ [6]. Campuran direndam selama 24 jam dan wadahnya ditutup dengan aluminium foil untuk meminimalkan kontak langsung dengan cahaya. Penyaringan kemudian dilakukan untuk memperoleh ekstrak pigmen dari kulit buah manggis [8]. 


\section{Pengendapan Pasta $\mathrm{TiO}_{2}$ pada Kaca LCD}

Kaca substrat LCD dengan luasan 2,5 cm x 2,5 cm direndam dengan etanol sebelum dilapisi. Tepi substrat sepanjang $2 \mathrm{~cm}$ dan 1,5 cm dari tepi diberi isolasi untuk mengontrol kerapian deposisi $\mathrm{TiO}_{2}$ dan ketebalan lapisan. Pasta $\mathrm{TiO}_{2}$ diletakkan pada tepi substrat, kemudian diratakan dengan spatula. Lapis tipis $\mathrm{TiO}_{2}$ dibiarkan kering di udara terbuka, kemudian isolasi dilepas. Kaca berlapis $\mathrm{TiO}_{2}$ kemudian dipanaskan dalam tungku listrik (furnace) pada suhu $450{ }^{\circ} \mathrm{C}$ selama 30 menit.

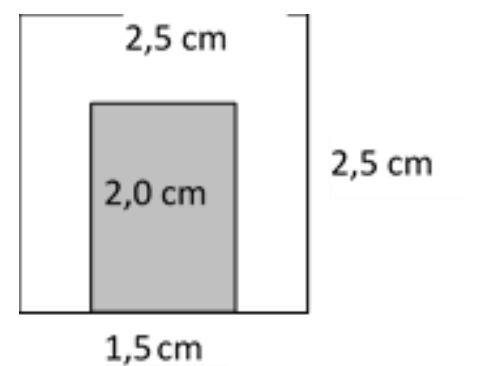

Gambar 1. Ilustrasi skema area deposisi $\mathrm{TiO}_{2}$

Perendaman Kaca LCD Terdeposisi $\mathrm{TiO}_{2}$ pada Larutan Pigmen Kulit Buah Manggis

Lapisan $\mathrm{TiO}_{2}$ direndam dalam larutan pigmen kulit buah manggis selama kurang lebih 30 menit kemudian lapisan $\mathrm{TiO}_{2}$ akan menjadi berwarna merah-jingga.

\section{Pembuatan Elektrolit}

Kalium Iodida (KI) sebanyak 0,83 g dilarutkan dalam $10 \mathrm{~mL}$ asetonitril kemudian diaduk sampai larut. Setelah itu ditambahkan 0,127 $\mathrm{g} \mathrm{I}_{2}$ dalam larutan tersebut dan diaduk hingga larut sempurna. Larutan kemudian disimpan dalam botol tertutup [8].

\section{Pembuatan Elektroda Perlawanan Karbon}

Polivinil Alkohol (PVA) sebanyak 0,5 gram ditambahkan kedalam akuades, kemudian diaduk dan dipanaskan di atas tungku pemanas yang berfungsi sebagai pengikat dalam pembuatan pasta. Suspensi tersebut ditambahkan pada serbuk karbon sebagai katalis karbon. Pasta grafit dilapiskan ke kaca LCD pada bagian konduktifnya kemudian dipanaskan pada temperatur $450^{\circ} \mathrm{C}$ selama 10 menit agar karbon membentuk kontak yang baik sesama partikel karbon dan dengan kaca konduktif LCD [8].

\section{Perakitan dan pengukuran Efisiensi DSSC}

DSSC dirakit menjadi model berlapis (sandwich) dengan elektroda perlawanan diletakkan berhadapan dengan lapisan $\mathrm{TiO}_{2}$. DSSC kemudian dijepit agar strukturnya mantap. Elektrolit kemudian diteteskan pada sela-sela ruang antar elektroda. Rancangan DSSC kemudian ditentukan nilai efisiensinya dengan alat hambatan geser ALPHA 10k $\Omega$ dan multimeter digital HELES. Pengukuran dilakukan dengan memvariasi tegangan menggunakan hambatan geser hingga diperoleh tegangan rangkaian terbuka $\left(\mathrm{V}_{\mathrm{oc}}\right)$ dan arus hubung singkat $\left(\mathrm{I}_{\mathrm{sc}}\right)$. Pengukuran dilakukan pada kondisi di bawah sinar matahari langsung.

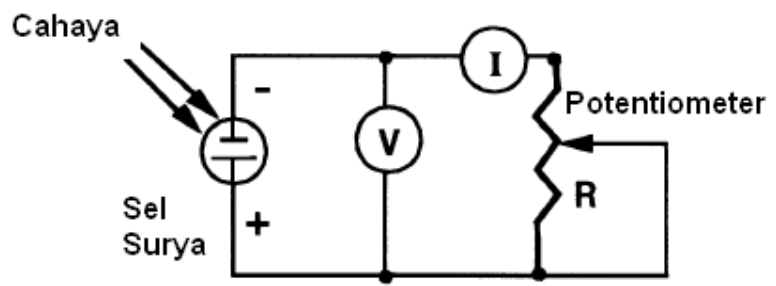

Gambar 2. Skema rangkaian listrik pengujian efisiensi DSSC

\section{Hasil dan Pembahasan}

Analisis Serapan Zat Warna Antosianin Kulit Manggis

Pada analisis larutan zat warna dengan menggunakan instrumen spektrofotometer UV-Vis dengan panjang gelombang antara $450 \mathrm{~nm}-600 \mathrm{~nm}$ diperoleh panjang gelombang maksimum sebesar 510 nm dengan absorbansi 0,165. Hal itu menunjukkan bahwa zat warna tersebut menyerap spektrum pada gelombang tampak pada panjang gelombang $510 \mathrm{~nm}$. Spektrum tampak pada panjang gelombang tersebut adalah spektrum warna biru-hijau. Oleh karena itu, zat warna antosianin pada kulit manggis berwarna merah karena menyerap spektrum biru-hijau dan mamantulkan warna merah.

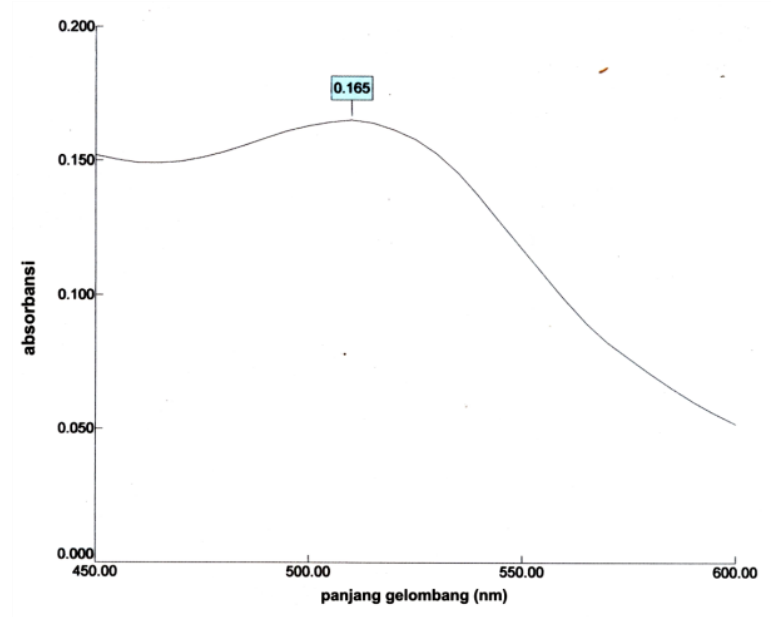

Gambar 3. Spektra ultraviolet-tampak larutan pewarna kulit buah manggis

Senyawa antosianin dalam larutan asam membentuk ion oksonium dan menghasilkan konjugasi ikatan rangkap yang melalui tiga gugus aglikon yang membantu menyerap foton pada spektrum tampak. Warna merah pada senyawa antosianin menunjukkan adanya gugus glukosida yang terikat pada suatu senyawa sianidin [9].

Karakterisasi Lapis Tipis $\mathrm{TiO}_{2}$

Lapis tipis $\mathrm{TiO}_{2}$ dalam DSSC berfungsi sebagai bahan semikonduktor yang pita konduksinya akan ditempati oleh elektron terinjeksi dari molekul antosianin karena telah tereksitasi oleh cahaya. Untuk dapat mengeksitasi elektron dari molekul antosianin ke pita konduksi semikonduktor, $\mathrm{TiO}_{2}$ harus berikatan dengan molekul antosianin terlebih dahulu. Kemudahan berikatan antara molekul antosianin dengan $\mathrm{TiO}_{2}$ 
ditentukan oleh bentuk permukaan dan fase kristal dari $\mathrm{TiO}_{2}$. Sedangkan kemampuan mengalirnya elektron dari pita konduksi semikonduktor ke rangkaian DSSC dipengaruhi oleh ketebalan penampang melintang dari lapis tipis $\mathrm{TiO}_{2}[10]$.

Karakteristik lapis tipis $\mathrm{TiO}_{2}$ dianalisis melalui dua metode yaitu metoda scanning electron microscopy (SEM) dan metoda difraksi sinar X. Analisis SEM bertujuan untuk mengetahui bentuk permukaan dan ketebalan dari lapis tipis $\mathrm{TiO}_{2}$. Analisis dengan metode difraksi sinar X (XRD) bertujuan untuk mengetahui karakteristik fase kristal dari lapis tipis $\mathrm{TiO}_{2}$.

Karakterisasi Bentuk Permukaan dan Ketebalan Bagian Melintang (Cross Section) Lapis Tipis $\mathrm{TiO}_{2}$

Analisis karakteristik bentuk permukaan dan ketebalan lapis tipis $\mathrm{TiO}_{2}$ ditentukan dengan metode SEM. Hasil yang didapatkan dari analisis bentuk permukaan lapis tipis adalah berongga-rongga dengan ukuran rongga berkisar antara $135 \mathrm{~nm}$ sampai dengan $693 \mathrm{~nm}$ dan ukuran kristal $\mathrm{TiO}_{2} 148 \mathrm{~nm}$. Permukaan $\mathrm{TiO}_{2}$ yang berukuran sampai skala nanometer merupakan ukuran yang optimal sebagai suatu bahan semikonduktor kristal nano. Rongga pada permukaan lapis tipis berfungsi dalam adsorpsi molekul antosianin ke $\mathrm{TiO}_{2}$. Jumlah dan luas rongga mempengaruhi efektivitas adsorpsi molekul zat warna antosianin ke dalam permukaan lapis tipis $\mathrm{TiO}_{2}[11]$.

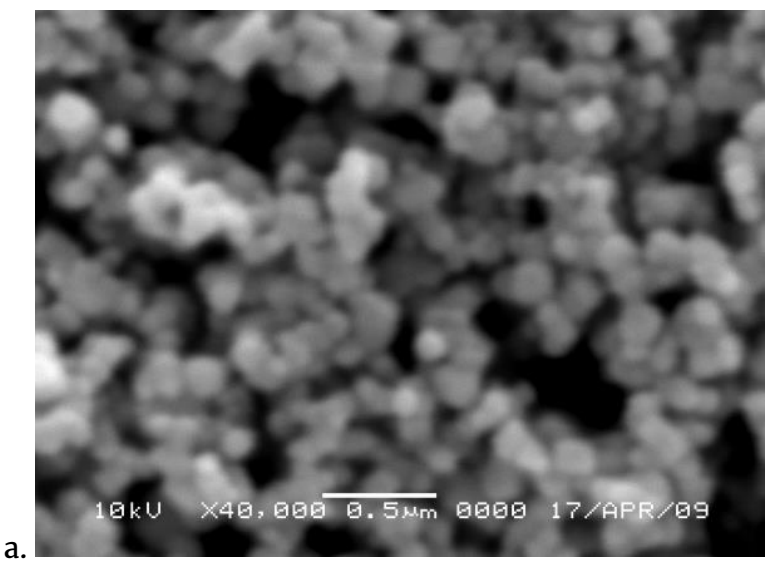

b.

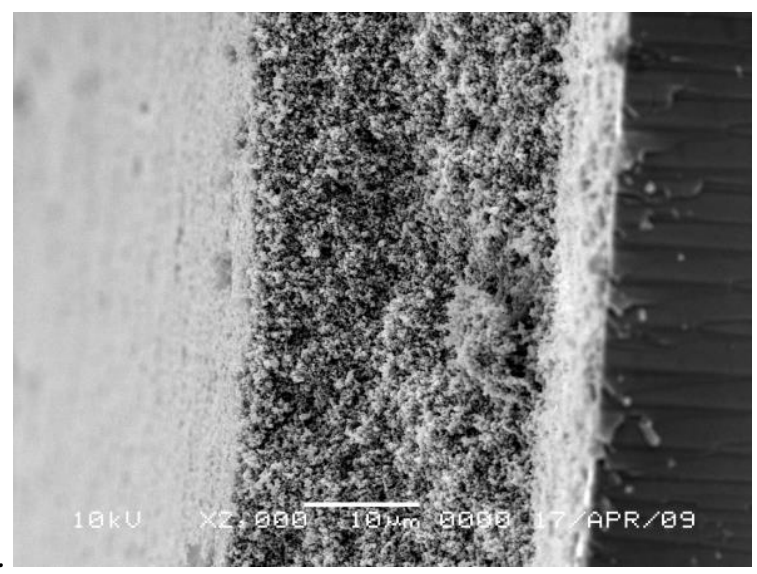

Gambar 4. Permukaan lapis tipis $\mathrm{TiO}_{2}$ hasil pencitraan scanning electron microscope (SEM) pada perbesaran 40.000 kali (a). Penampang melintang (cross section) lapis tipis $\mathrm{TiO}_{2}$ hasil pencitraan scanning electron microscope (SEM) dengan perbesaran 2000 kali (b).
Analisis ketebalan lapis tipis $\mathrm{TiO}_{2}$ dilakukan dengan pengukuran ketebalan penampang melintang dari lapis tipis $\mathrm{TiO}_{2}$ tersebut. Penampang melintang lapis tipis $\mathrm{TiO}_{2}$ dari hasil pencitraan SEM mempunyai ketebalan 25,4 $\mu \mathrm{m}$. Ketebalan penampang melintang lapis tipis $\mathrm{TiO}_{2}$ mempengaruhi efektivitas aliran elektron dalam rangkaian. Semakin tipis lapisan $\mathrm{TiO}_{2}$ maka semakin efektif kinerja dari DSSC [10].

\section{Karakterisasi Fase Kristal Lapis Tipis $\mathrm{TiO}_{2}$}

Karakterisasi fase kristal $\mathrm{TiO}_{2}$ dengan metode difraksi sinar X (XRD) bertujuan untuk megetahui fase kristal dari $\mathrm{TiO}_{2}$ yang digunakan dalam pembuatan lapis tipis $\mathrm{TiO}_{2}$ pada DSSC. Difraktogram hasil analisis kemudian dibandingkan dengan data standar primer $\mathrm{TiO}_{2}$ dari ICSD (Inorganic Crystal Structure Database).

Hasil yang didapatkan menunjukkan bahwa fase kristal dari $\mathrm{TiO}_{2}$ adalah anatase setelah dibandingkan dengan data primer $\mathrm{TiO}_{2}$. Fase kristal yang didapatkan merupakan anatase karena pada proses sintering pada furnace digunakan temperatur $450^{\circ} \mathrm{C}$. $\mathrm{TiO}_{2}$ membentuk kristal anatase yang stabil pada suhu sampai $500^{\circ} \mathrm{C}$ dan membentuk kristal rutil pada suhu $700^{\circ} \mathrm{C}$.

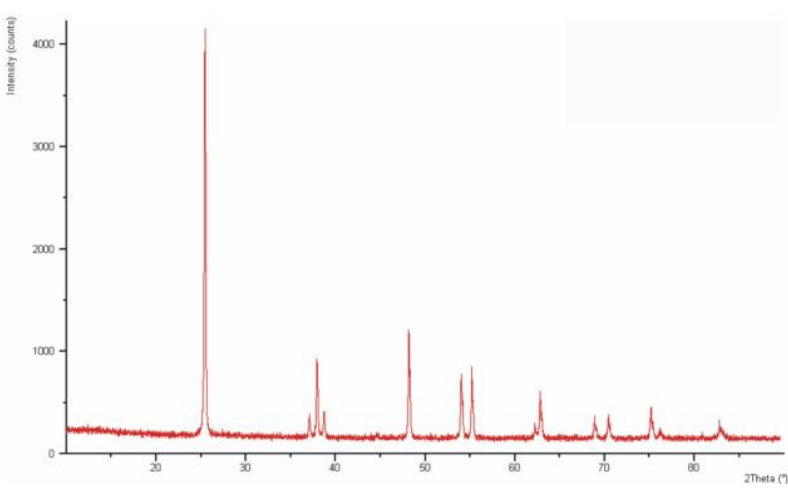

Gambar 5. Difraktogram $\mathrm{TiO}_{2}$ hasil analisis

Fase kristal anatase $\mathrm{TiO}_{2}$ paling efektif digunakan dalam pembuatan lapis tipis pada DSSC karena luas permukaannya mampu menghasilkan daya adsorpsi yang efektif terhadap molekul pewarna dan fase kristalnya stabil pada suhu rendah.

\section{Karakterisasi Ikatan Molekul Pewarna dengan $\mathrm{TiO}_{2}$}

Syarat terjadinya arus listrik pada rangkaian DSSC salah satunya adalah terjadinya ikatan antara molekul pewarna antosianin dengan $\mathrm{TiO}_{2}$. Hal itu disebabkan molekul antosianin yang telah berikatan dengan $\mathrm{TiO}_{2}$ akan tereksitasi dan elektronnya akan dialirkan ke kaca penghantar melewati pita konduksi semikonduktor $\mathrm{TiO}_{2}$. Elektron inilah yang akan menyebabkan terjadinya arus listrik pada rangkaian. Apabila molekul antosianin tidak berikatan dengan $\mathrm{TiO}_{2}$ maka elektronnya setelah mengalami eksitasi tidak akan dialirkan melalui $\mathrm{TiO}_{2}$ karena tidak berikatan. Elektron dari senyawa antosianin melainkan akan kembali ke keadaan dasarnya sehingga tidak akan ada arus yang mengalir karena tidak ada perpindahan elektron.

Ikatan yang terjadi pada senyawa pewarna antosianin dengan $\mathrm{TiO}_{2}$ dapat terjadi melalui suatu 
ikatan kelat. Ikatan tersebut dapat terjadi antara gugus hidroksil dari antosianin dan gugus $\mathrm{Ti}^{4+}$ pada $\mathrm{TiO}_{2}$.

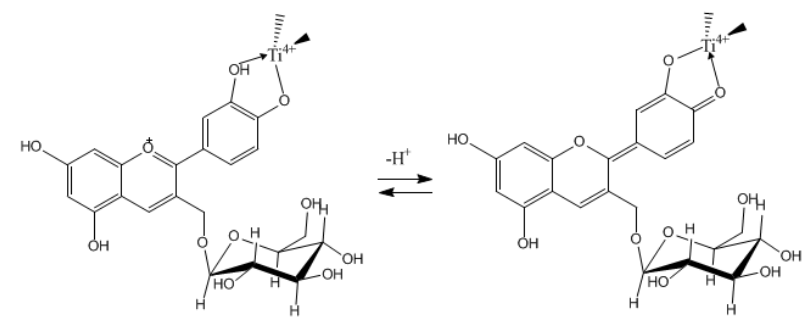

Gambar 6. Ikatan kelat yang terjadi antara gugus $\mathrm{Ti}^{4+}$ dengan molekul antosianin

Untuk mengetahui karakteristik ikatan kelat tersebut maka dilakukan analsisis menggunakan FTIR. Analisis dilakukan dengan membandingkan spektra gugus fungsi zat pewarna dan spektra gugus fungsi dari $\mathrm{TiO}_{2}$-zat warna.

Dari hasil analisis spektra FTIR zat pewarna diperoleh hasil sebagai berikut. Serapan di daerah $3444,27 \mathrm{~cm}^{-1}$ menunjukkan bahwa terdapat gugus hidroksil dalam senyawa dalam larutan. Gugus $\mathrm{OH}$ ini menunjukkan adanya gugus $\mathrm{OH}$ pada senyawa antosianin ataupun senyawa alkohol dalam larutan. Senyawa alkohol dalam larutan berasal dari salah satu penyusun pelarut antosianin yaitu etanol. Senyawa alkohol juga dapat dimungkinkan terbentuk dari hidrolisis glukosida yang terdapat pada antosianin menjadi alkohol yang disebut aglikon dan molekul gula. Pita kuat dan medium pada bilangan gelombang 1644,65 $\mathrm{cm}^{-1}$ menunjukkan adanya gugus karbonil pada larutan. Gugus karbonil ini muncul karena adanya kesetimbangan senyawa antosianin yang berada dalam bentuk sianin kuinonoid. Serapan pada bilangan gelombang 1560 dan $1515 \mathrm{~cm}^{-1}$ menunjukkan adanya cincin aromatik. Serapan pada 1455,80; 1395,62 dan $1278,63 \mathrm{~cm}^{-1}$ menunjukkan ikatan $\mathrm{C}-\mathrm{H}$. Serapan pada $573,25 \mathrm{~cm}^{-1}$ menunjukkan adanya gugus benzena tersubtitusi.

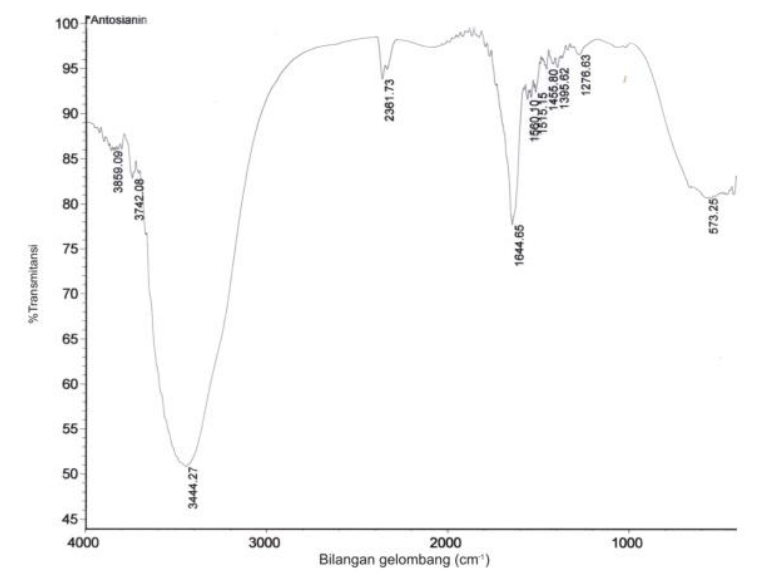

Gambar 7. Spektra inframerah zat pewarna dari kulit manggis

Pada spektra FTIR $\mathrm{TiO}_{2}$-pewarna didapatkan hasil yang berbeda dari spektra FTIR larutan pewarna. Perbedaan ditunjukkan pada nilai transmitansi, jumlah serapan, dan pergeseran nilai bilangan gelombang dari serapan. Nilai pergeseran serapan ke arah lebih panjang maupun lebih pendek disebabkan oleh efek pelarut ataupun subtitusi. Munculnya pita serapan baru pada bilangan gelombang 1076,05 $\mathrm{cm}^{-1}$ menunjukkan adanya gugus $\mathrm{C}-\mathrm{O}$. Hal ini disebabkan pada ikatan $\mathrm{TiO}_{2}$ dengan senyawa antosianin pada saat berbentuk sianin flavilium. Munculnya pita kuat lebar pada daerah bilangan gelombang $686,78 \mathrm{~cm}^{-1}$ menunjukkan adanya $\mathrm{TiO}_{2}$ sebagai lapis tipis yang berikatan khelat dengan senyawa antosianin.

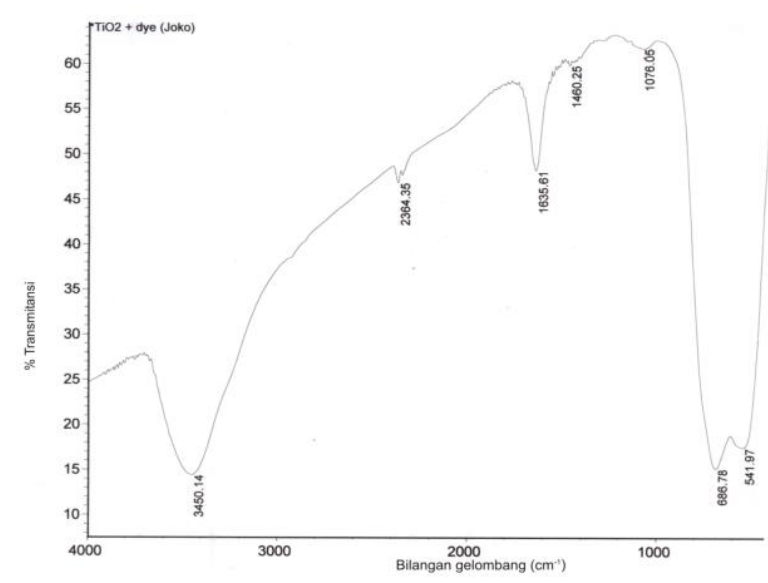

Gambar 8. Spektra inframerah $\mathrm{TiO}_{2}$-pewarna

\section{Penentuan Efisiensi DSSC}

Penentuan efisiensi DSSC dilakukan dengan metode kurva arus dan tegangan. Tujuan dari penentuan efisiensi dari DSSC adalah untuk mengetahui keefektifan dari satu susunan komponen DSSC dalam mengubah energi matahari menjadi energi listrik yang dinyatakan dalam persen. Metode kurva arus dan tegangan menggunakan variasi nilai hambatan untuk menentukan besaran-besaran yang dibutuhkan dalam pengukuran efisiensi DSSC. Besaran tersebut adalah tegangan rangkaian terbuka $\left(V_{o c}\right)$, arus hubung pendek $\left(I_{s c}\right)$, tegangan optimum $\left(V_{m p p}\right)$, arus optimum $\left(I_{m p p}\right)$ dan fill factor $(F F)$.

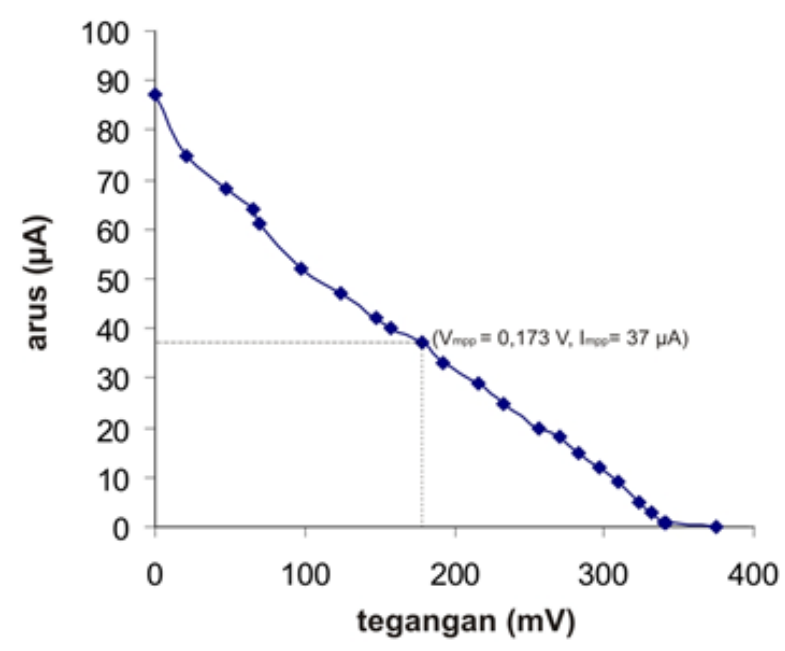

Gambar 9. Kurva arus-tegangan DSSC 
Nilai efisiensi menunjukkan keefektifan DSSC dalam mengubah energi cahaya matahari menjadi energi listrik.

Tabel 1. Pengukuran berbagai nilai besaran dan efisiensi pada DSSC

\begin{tabular}{cc}
\hline Besaran & Nilai \\
\hline$V_{o c}$ & $0,375 \mathrm{~V}$ \\
$I_{s c}$ & $87 \mu \mathrm{A}$ \\
$V_{m p p}$ & $0,178 \mathrm{v}$ \\
$I_{m p p}$ & 37 \\
$F F$ & 0,202 \\
$P_{\max }$ & $6,59025 \times 10^{-6} \mathrm{~W}$ \\
$\eta$ & $0,0022 \%$ \\
\hline
\end{tabular}

Pengubahan energi cahaya menjadi listrik dalam DSSC berdasar pada suntikan elektron dari molekul antosianin sebagai pensensitisasi yang tereksitasi karena adanya foton ke pita konduksi $\mathrm{TiO}_{2}$. Elektron kemudian mengalir melalui rangkaian dan terkumpul di elektroda perlawanan. Pasangan redoks elektrolit $\mathrm{I}_{3}^{-} / \mathrm{I}^{-}$ akan memberikan elektron ke molekul antosianin yang telah kehilangan elektronnya akibat peristiwa suntikan elektron ke pita konduksi $\mathrm{TiO}_{2}$. Proses ini akan berulang terus-menerus selama terdapat cahaya sebagai pengeksitasi elektron dari molekul antosianin.

Nilai tegangan yang dihasilkan karena adanya perbedaan muatan pada elektroda kerja (working electrode) dan elektroda perlawanan (counter elektroda) sehingga terdapat nilai beda potensial yang dinyatakan sebagai tegangan. Nilai kuat arus menginterpretasikan elektron yang mengalir melalui rangkaian dari kutub negatif yatu elektroda kerja ke kutub positif yaitu elektroda perlawanan.

Nilai efisiensi yang diperoleh dalam penelitian ini sangat kecil yaitu $0,0022 \%$. Hal ini berbeda jauh dengan nilai efisiensi dalam penelitian pembuatan DSSC menggunakan senyawa antosianin dari buah beri hitam $^{[3]}$ yaitu sebesar $1 \%$. Nilai efisiensi yang kecil disebabkan oleh beberapa faktor. Faktor tersebut antara lain keterbatasan sensitisasi yang dilakukan oleh molekul antosianin ke pita konduksi $\mathrm{TiO}_{2}$ karena hanya mampu membentuk satu ikatan khelat. Hal itu berbeda dengan senyawa pensensitisasi kompleks rhutenium jenis N3 yang mempunyai empat gugus karboksilat yang masing-masing mempunyai tiga kemungkinan untuk berikatan dengan $\mathrm{TiO}_{2}$ yaitu membentuk ikatan monodentat, kelat atau multidentat. Efisiensi juga disebabkan oleh sinar matahari yang datang tidak sepenuhnya digunakan karena sebagian dipantulkan oleh bahan kaca LCD sehingga mengurangi efektifitas dari DSSC. Elektrolit yang digunakan mempunyai waktu penggunaan yang pendek karena mudah rusak dan menguap karena panas.

Secara keseluruhan, senyawa antosianin dapat digunakan sebagai senyawa pensensitisasi alternatif pengganti kompleks rhutenium pada DSSC karena mampu menyerap gelombang tampak polikromatik dari cahaya matahari, berinteraksi dengan $\mathrm{TiO}_{2}$ dan dapat mengeksitasi elektron yang kemudian menghasilkan arus listrik meskipun dengan nilai efisiensi yang sangat kecil.

\section{Kesimpulan}

Dari hasil penelitian dapat disimpulkan bahwa senyawa antosianin dari kulit buah manggis dapat digunakan sebagai pewarna peka cahaya (dye sensitizer) alternatif pada rangkaian DSSC dan menghasilkan nilai efisiensi ebesar 2,2 x 10 $0^{-3}$. Karakterisasi serapan panjang gelombang tampak maksimum larutan pewarna dengan metode spektrofotometri UV-Vis adalah $510 \mathrm{~nm}$, kristal $\mathrm{TiO}_{2}$ menunjukkan fase anatase dengan metode difraksi sinar X, pori dan kristal $\mathrm{TiO}_{2}$ dengan karakterisasi SEM menunjukkan ukurannya telah menunjukkan skala nano dan karakterisasi dengan FTIR menunjukkan senyawa pewarna mengandung gugus fungsi karbonil dan hidroksil serta mampu berikaan khelat dengan $\mathrm{TiO}_{2}$.

\section{Daftar Pustaka}

[1] Michael Gratzel, Photoelectrochemical cells, Nature, 414, 6861, (2001) 338-344

[2] Samina Ali, Biomimicry in Solar Energy Conversion with Natural Dye-Sensitized Nanocrystalline Photovoltaic Cells, Department of Chemistry and Biochemistry, Oberlin College, Oberlin, Ohio

[3] Michael Grätzel, Dye-sensitized solar cells, Journal of Photochemistry and Photobiology C: Photochemistry Reviews, 4, 2, (2003) 145-153 https://doi.org/10.1016/S1389-5567(03)00026-1

[4] Khwanchit Wongcharee, Vissanu Meeyoo, Sumaeth Chavadej, Dye-sensitized solar cell using natural dyes extracted from rosella and blue pea flowers, Solar Energy Materials and Solar Cells, 91, 7, (2007) 566-571

https://doi.org/10.1016/j.solmat.2006.11.005

[5] A. C. Muñoz-Espada, K. V. Wood, B. Bordelon, B. A. Watkins, Anthocyanin Quantification and Radical Scavenging Capacity of Concord, Norton, and Marechal Foch Grapes and Wines, Journal of Agricultural and Food Chemistry, 52, 22, (2004) 67796786 http://dx.doi.org/10.1021/jf040087y

[6] Nerine J. Cherepy, Greg P. Smestad, Michael Grätzel, Jin Z. Zhang, Ultrafast Electron Injection: Implications for a Photoelectrochemical Cell Utilizing an Anthocyanin Dye-Sensitized TiO2 Nanocrystalline Electrode, The Journal of Physical Chemistry B, 101, 45, (1997) 9342-9351 http://dx.doi.org/10.1021/jp972197w

[7] Sujitra Ratanamarno, Uthaibutra, Jamnong, Kobkiat Saengnil, Effects of bagging and storage temperature on anthocyanin content and phenylalanine ammonialyase (PAL) activity in mangosteen (Garcinia mangostana L.) fruit pericarp during maturation, Songklanakarin Journal of Science and Technology 27, 4, 712-717

[8] Wilman Septina, Pembuatan Prototipe Solar Cell Murah dengan Bahan Organik-Inorganik (Dyesensitized Solar Cell), in: Laporan Penelitian Bidang Energi, Institut Teknologi Bandung, 2007. 
[9] J. M. R. C. Fernando, G. K. R. Senadeera, Natural anthocyanins as photosensitizers for dye-sensitized solar devices, Current Science, 95, 5, (2008) 663-666

[10] Yong Liu, Hui Shen, Xiaorui Huang, Youjun Deng, A new improved structure of dye-sensitized solar cells with reflection film, Chinese Science Bulletin, 51, 3, (2006) 369-373 10.1007/s11434-006-0369-0

[11] Jae-Wook Lee, Kyung-June Hwang, Wang-Geun Shim, Kyung-Hee Park, Hal-Bon Gu, Kyu-Hyuk Kwun, Energetic surface heterogeneity of nanocrystalline $\mathrm{TiO} 2$ films for dye-sensitized solar cells, Korean Journal of Chemical Engineering, 24, 5, (2007) 847-850 http://dx.doi.org/10.1007/s11814007-0052-4 